\title{
PERANAN PAJAK DAERAH TERHADAP PEMBANGUNAN EKONOMI KABUPATEN LABUHANBATU
}

\author{
Nurintan Asyiah Siregar \\ Dosen Tetap Sekolah Tinggi Ilmu Ekonomi (STIE) Labuhanbatu
}

\begin{abstract}
ABSTRAK
Pajak merupakan kontribusi orang ke kas negara terhadap hukum (bisa dipaksakan) dengan tidak bisa menyeimbangkan pendapatan. Yang memiliki tujuan dan digunakan untuk pemukiman umum. Seperti kita ketahui bahwa pajak memiliki bagian dari peningkatan pembangunan ekonomi. Pembangunan ekonomi merupakan proses yang dapat meningkatkan pendapatan masyarakat percapita untuk program jangka panjang. Dalam hal ini, penulis menganalisis bagian pajak daerah pembangunan ekonomi di Labuhanbatu. Alasan memilih pajak daerah sebagai variabel bebas karena pajak daerah merupakan salah satu sumber pendapatan asli daerah yang memiliki peran penting dalam pembangunan ekonomi di Labuhanbatu. Perkiraan dari model regresi pembangunan ekonomi (PDRB) dengan pajak daerah sebagai variabel independen dengan menggunakan eviews 4.1 program, kita mengetahui bahwa pajak daerah berpengaruh signifikan terhadap perkembangan ekonomi di Labuhanbatu.
\end{abstract}

\section{PENDAHULUAN}

Pelaksanaan pembangunan nasional merupakan tugas bangsa yang tidak

berkesudahan dalam mengisi kemerdekaan demi tercapainya tujuan nasional sesuia dengan cita-cita proklamasi yaitu mewujudkan masyarakat adil dan makmur sesuai dengan pancasila dan Undang-undang Dasar 1945.

Pembangunan ekonomi didefinisikan sebagi suatu proses yang menyebabkan pendapatan perkapita suatu masyarakat meningkat dalam jangka panjang. Pembangunan dilaksanakan meratakan bukanlah hanya untuk satu golongan atau sebagian daerah tetapi haruslah dapat dinikmati oleh seluruh masyarakat.

Mengingat sasaran pembangunan bukan hanya semata-mata untuk kepentingan pemerintah, malinkan untuk kepentingan seluruh bangsa dikaitkan dengan kehidupan bernegara yang demokratis, jadi demokratisasi tidak terbatas hanya pada demokratis manfaat tetapi juga mencakup pada demokratisasi tanggung jawab, hal ini berarti bahwa pembangunan yang telah dicanangkan melalui operasional GBHN, bukan hanya tanggung jawab pemerintah saja tetapi menjadi tanggung jawab seluruh warga negara. Adanya hak untuk menikmati hasilhasil pembangunan akan lebih nikmat merasakannya apabila kita melaksanakan kewajiban terlebih dahulu.

Kehidupan masyarakat dan perekonomian Indanesia yang sebagian besar bercorak agraris, hal ini dapat dilihat dari besarnya sumbangan sektor pertanian terhadap pendapatan nasional dan sebagian besar penduduk Indonesia yang bertempat tinggal di pedesaan. Dalam hal ini bumi dan kekayaan alam yang terkandung didalamnya mempunyai peranan penting dalam pembangunan masyarakat kearah yang lebih baik. Oleh karena itu, bagi masyarakat yang memperoleh manfaat dari bumi dan kekayaan alam terkandung didalamnya, wajar kiranya menyerahkan sebagian dari kenikmatan atau hasil yang diperolehnya kepada negara melalui pembanyaran pejak. 
Sebagaimana kita ketahui bahwa pajak sebagai sumber penerimaan dalam negeri mempunyai potensi untuk dijadikan sumber pendapatn nasional. Ini dapat dilihat dari jumlah penduduk yang besar dan wilayah negara kita yang luas sehingga akan memungkinkan penerimaan dari pajak akan besar.

Sebelum adanya otonomi daerah sumber pendapatan daerah masih mengaju pada Undang-Undang No.5 Tahun 1974, dimana jenis-jenis pendapatan daerah diatur berdasarkan Undang-Undang No. 11 dan 12 Tahun 1956, dan berbagai peraturan lainnya. Berdasarkan Undang-Undang No.11 dan 12 Tahun 1956 ini memang ada beberapa pajak pusat yang diserahkan kepada daerah, namun dari sekian banyak pajak daerah tersebut hanya beberapa saja yang akhirnya menjadi sumber penting bagi pendapatan asli daerah yang menyebabkan rendahnya sumbangan pajak terhadap pendapatan asli daerah.

Dengan adanya otonomi daerah yang dilaksanakan mulai tanggal 1 Januari 2001 melalui Undang-Undang No.22 Tahun 1999 dan Undang-Undang No.25 Tahun 1999 tentang perimbangan keuangan antara Pusat dan Daerah, maka setiap daerah mempunyai peluang yang lebih besar untuk meningkatkan pendapatan asli daerahnya dan juga menyebabkan kebijakkan yang menyangkut keuangan daerah dan APBD mengalami perubahan. Berdasarkan UndangUndang No.33 Tahun 2004 yang merupakan penyempurnaan dari Undang-Undang No.18 Tahun 1997 yang menyatakan bahwa pajak daerah adalah iuran wajib yang dapat dipaksakan kepada setiap orang (wajib pajak) tanpa kecuali. Ditegaskan pula bahwa hasil pajak daerah itu diperuntukkan bagi penyelenggaraan pemerintah dan pembangunan daerah. Undang-Undang No.33 Tahun 2004 ini merupakan landasan hukum bagi pemerintah daerah dalam mengeluarkan peraturan daerah (perda) untuk memungut pajak di daerah masing-masing, hal ini juga didukung oleh PP No.65 Tahun 2001. Diharapkan dengan keluarnya Undang-Undang No.33 Tahun 2004 dan PP No.65 Tahun 2001 ini adanya kemandirian bagi setiap daerah terutama daerah tingkat II dalam membiayai pembangunannya yaitu dengan cara menggali sumber dana yang bersumber dari daerah itu sendiri.

Berdasarkan uraian tersebut maka penulis tertarik untuk melakukan penelitian mengenai pajak daerah. Adapun judul yang diketengahkan adalah "Peranan Pajak Daerah Terhadap Pembangunan Ekonomi Kabupaten Labuhanbatu".

\section{Perumusan Masalah}

Berdasarkan uraian tersebut maka penulis mengidentifikasikan masalah yang berhubungan dengan pembangunan Ekonomi, dengan merumuskan masalah yang dapat diambil sebagai dasar kajian dalam penelitian yang dilakukan anatara lain :

Bagaimana peranan pajak daerah terhadap pembangunan ekonomi Kabupaten Labuhanbatu.

\section{Hipotesis}

Hipotesis adalah pernyataan atau jawaban sementara terhadap penelitian. Berdasarkan permasalahan di atas maka sebagai jawaban sementara, penulis mengemukakan hipotesisnya adalah Pajak daerah mempunyai pengaruh positif terhadap pembangunan ekonomi Kabupaten Labuhanbatu, Ceteris Paribus.

\section{Tujuan Dan Manfaat Penelitian}

Tujuan dari penelitian ini adalah :

1. Untuk mengetahui bagaimana peranan pajak daerah dalam meningkatkan pembangunan ekonomi Kabupaten Labuhanbatu.

2. Untuk mengetahui prospek perkembangan pembangunan ekonomi Kabupaten Labuhanbatu. 
Manfaat yang diharapkan dari penelitian ini adalah sebagai berikut:

1. Hasil penelitian ini diharapkan bermanfaat sebagai bahan masukan bagi para perencana dan penentu keputusan pembangunan daerah, khususnya bagi perencanaan pembangunan Kabupaten Labuhanbatu.

2. Hasil penelitian ini diharapkan dapat meningkatkan khasanah penelitian di bidang Ekonomi Pembangunan, Ekonomi Regional, dan Ekonomi Kependudukan.

\section{Landasan Teori}

\section{Pembangunan Daerah}

Pembangunan daerah sebagai bagian yang integral dari pembangunan nasional pada hakekatnya adalah upaya untuk meningkatkan kapasitas pemerintah daerah sehingga tercipta suatu kemampuan yang handal dan profesional dalam menjalankan pemerintahan serta memberikan pelayanan yang prima kepada masyarakat. Pembangunan daerah juga berarti meningkatkan kemampuan daerah dalam mengelolah sumber daya ekonominya secara berdaya guna dan berhasil guna untuk kemajuan daerah dan kesejahteraan masyarakat.

Pembangunan daerah dapat dilakukan dengan dua pendekatan, yaitu pertama, pendekatan sentralistik dan kedua, pendekatan desentralistik. Pendekatan sentralistik mengandung arti bahwa pelaksanaan pembangunan sepenuhnya merupakan wewenang pusat dan sepenuhnya dilaksanakan oleh para birokrat di pusat. Sedangkan pendekatan desentralistik mengandung arti bahwa pembangunan daerah sebagian besar merupakan wewenang daerah dan dilaksanakan sendiri oleh daerah (Pemda) secara otonom. Pembangunan daerah melalui desentralisasi atau otonomi daerah memberikan peluang dan kesmpatan bagi terwujudnya pemerintahan yang bersih dan baik (good govermance) di daerah. Artinya, pelaksanaan tugas pemerintah daerah harus dilaksanakan atas prinsip efektif, efisien, partisipatif, terbuka (Tranparency), dan akuntabel (Accountability).

\section{Pengertian Pembangunan Ekonomi dan Pertumbuhan Ekonomi}

Pembangunan pada dasarnya untuk menngkatkan harkat, martabat, kualitas, kesejahteraan segenap lapisan masyarakat. Dalam kerangka ini pembangunan harus dipandang sebagai suatu rangkaian proses yang berjalan secara berkesinambungan untuk mewujudkan pencapaian tujuan. Proses meningkatnya pendapatan masyarakat secara riil adalah merupakan tujuan dari seluruh kebijakan pembangunan ekonomi. Pembangunan ekonomi adalah merupakan komponen yang esensial dari usaha pembangunan yang dijalankan oleh suatu masyarakat. Pembangunan ekonomi hanya meliputi usaha dari suatu masyarakat untuk mengembangkan kegiatan ekonomi hanya meliputi usaha dari suatu masyarakat untuk mengembangkan kegiatan ekonomi dan menikkan tingkat pendapatan masyarakat, sedangkan pembangunan dalam pengertian yang paling mendasar harus mencakup masalah materi dan financial dalam kehidupan masyarakat.

Pembanguan ekonomi telah digariskan kembali dengan dasar mengurangi dan menghapuskan kemiskinan, ketimpangan dan pengangguran dalam konteks pertumbuhan ekonomi atau ekonomi yang sedang berkembang,(Todaro, 1983:123). Jadi dengan adanya pembatasan antara pembangunan dengan pembangunan ekonomi, maka pembangunan ekonomi didefinisikan sebagai :"suatu proses yang menyebabkan pendapatan perkapita penduduk suatu negara meningkat dalam jangka panjang. (Sukirno, 1985:13).

3. Keuangan Daerah.

Untuk memperoleh gambaran mengenai kemampuan daerah dalam berpartisipasi dalam program-program pembangunan maka perlu dilihat dari aspek keuangannya. Berbicara mengenai aspek keuangan daerah, tentunya tidak terlepas dari administrasi keuangan daerah 
itu sendiri menyangkut masalah proses alokasi sumber-sumber pendapatannya serta kemampuan keuangan yang mendasarinya.

Kebijaksanaan pemberian sumber-sumber pembiayaan kepada daerah ini tidak terlepas kaitannya dengan otonomi daerah. Otonomi daerah tidak hanya terhenti pada aspek politik semata, tetapi otonomi daerah mempunyai banyak segi, seperti aspek ekonomi, sosial, budaya, dan lain-lain. Dalam proses pelaksanaan otonomi daerah membutuhkan dukungan sumber daya (resources) yang memadai dan cukup agar otonomi berhasil, oleh karena itu, kebijakan otonomi daerah dibarengi dengan kebijakan fiskal, sebagai langkah untuk mendukung dan meningkatkan kemampuan keuangan pemerintah daerah dalam melaksanakan otonomi. Dengan demikian otonomi selalu berhubungan erat dengan persoalan desentralisasi fiskal, kebijakan desentralisasi fiskal berimplikasi langsung terhadap keuangan daerah, dalam hal ini Anggaran Pendapatan dan Belanja Negara (APBN).

Sehubungan dengan pentingnya posisi keuangan daerah ini, Pamuji (1980:61) menegaskan bahwa :'Pemerintah daerah tidak dapat melaksanakan fungsinya dengan efektif dan efisien tanpa uang yang cukup untuk memberikan pelayanan, pembangunan dan keuangan inilah yang merupakan salah satu dasarnya".

Pendapat ini sejalan dengan PP Nomor 105 tahun 2000 yang menyatakan keuangan daerah adalah "semua hak dan kewajiban daerah dalam rangka penyelengaraan pemerintah dapat dinilai dengan uang termasuk didalamnya segala bentuk kekayaan yang berhubungan dengan hak dan kewajiban daerah tersebut dalam kerangka APBD.

\section{Pendapatan Asli Daerah}

Undang-undang otonomi daerah menegaskan bahwa dalam rangka melaksanakan asas desentralisasi dibentuk dan disusun oleh Provinsi, daerah kabupaten, dan daerah Kota yang berwenang mengatur dan mengurus kepentingan masyarakat setempat menurut prakarsa sendiri berdasarkan mgasyarakat (Pasal 4 ayat 1 UU No. 22 tahun 1999), sedangkan ekonomi, politik daerah, sosial budaya, sosial politik, jumlah penduduk, luas derah, dan pertimbagan lain yang memungkinkan terselenggaranya otonomi daerah (Pasal 5 ayat 1 UU No. 22 tahun 1999).

\section{Pajak}

Menurut Andriani pajak adalah “ iuran pada negara (yang dapat dipaksakan) yang terhutang oleh yang wajib membayarnya menurut peraturan-peraturan dengan tidak mendapat prestasi kembali, yang digunakan untuk membiayai pengeluaran-pengeluaran umum berhubungan dengan tugas negara untuk menyelenggarakan pemerintahan ".(Nurmantu; 2003:12).

Sedangkan menurut Soemitro (1990:12) menyatakan pajak adalah "iuran kepada kas negara berdasarkan undang-undang yang dapat dipaksakan dengan tidak mendapat jasa timbal (Kontraprestasi), yang langsung dapat ditujukan dan yang digunakan untuk membayar pengeluaran umum".

\section{Produk Domestik Regional Bruto (PDRB)}

Salah satu yang digunakan untuk mengukur tingkat perekonomian wilayah adalah dengan menggunakan besaran nilai Produk Domestik Regional Bruto (PDRB). Perubahan besaran PDRB atas dasar harga berlaku pada tahun penghitungan masih memuat akibat terjadinya inflasi/deflasi sehingga tidak memperlihatkan pertumbuhan atau perubahan PDRB secara riel. Sebaliknya, PDRB atas dasar harga konstan menggunakan harga pasar pada tahun dasar tertentu $(1983,1993)$ sehungga perubahan besaran PDRB sudah terlepas dari pengaruh inflasi/deflasi. 


\section{Metode Penelitian}

1. Lokasi Penelitian

Sesuai dengan judul, penelitian ini memusatkan pada pengkajian mengenai peranan pajak daerah terhadap pembangunan ekonomi di Labuhanbatu.

\section{Jenis dan Sumber Data}

Jenis data dalam penelitian ini adalah data kuantitatif yaitu data yang berbentuk angkaangka. Sedangkan sumber datanya berupa data sekunder yang berbentuk time series yang diperoleh dari berbagai instansi Pemerintah Daerah Kabupaten Labuhanbatu sebagai berikut :

- Dinas Pendapatan Daerah Kabupaten Labuhanbatu

- Badan Pusat Statistik (BPS) Kabupaten Labuhanbatu.

\section{Model Analisis Data}

Analisis yang digunakan untuk hipotesis diatas adalah alat analisis dengen regresi linier sederhana.

Model Persamaan adalah :

$$
\mathrm{Y}=\mathrm{a}+\mathrm{b} \mathrm{X}+\mathrm{e}
$$

Dimana :

$\mathrm{Y} \quad=$ Produk Domestik Regional Bruto (juta Rupiah)

$\mathrm{X} \quad=$ Pajak Daerah (juta Rupiah)

$\mathrm{a} \quad=$ konstanta

$\mathrm{b} \quad=$ koefisien regresi

e $\quad=$ Standard Error

sehingga bentuk hipotesisnya adalah:

$\frac{\delta y}{\delta x}>0$, artinya jika terjadi kenaikan pada $\mathrm{x}$ (pajak daerah), maka Y (Produk

Domestik Regional Bruto) mengalami kenaikan, ceteris paribus

\section{Alat Analisis}

1. Koefisien Determinasi $\left(\mathrm{R}^{2}\right)$

Koefisien determinasi digunakan untuk melibatkan seberapa besar variabel-variabel indpenden secara bersama-sama mampu memberikan penjelasan mengenai variabel dependen.

\section{Uji t-statistik}

Uji t-statistik merupakan pengujian hipotesis parsial untuk mengetauhi apakah variabel indpenden berpengaruh signifikan terhadap variabel dependen, dengan mengaggap variabel lainnya konstan.

Nilai thitung diperoleh dengan rumus

$\mathrm{t}_{\text {hitung }}=\frac{b}{s b}$

dimana :

$\mathrm{b}=$ parameter estimasi dari $\mathrm{X}$

$\mathrm{sb}=$ Standar error $\mathrm{X}$

Pengujian dilakukan melalui uji $t$ dengan membandingkan $t_{\text {hitung }}$ dengan $t_{\text {tabel }}$ pada $\alpha 0.05$. apabila hasil perhitungan menunjukkan :

1. Ha $: \mathrm{b} 1=0$ maka Ho diterima dan Ha ditolak 
Artinya variasi variabel bebas tidak dapat menerangkan variabel terikat dan terdapat pengaruh antara dua variabel yang diuji.

$t_{\text {hitung }}<t_{\text {tabel }}$, signifikan $>\alpha$ maka Ho diterima dan Ha ditolak

2. Ha $: \mathrm{b} 1 \neq 0$ maka Ho ditolak dan Ha diterima

Artinya variasi variabel bebas dapat menerangkan variabel terikat dan terdapat pengaruh antara dua variabel yang diuji.

$t_{\text {hitung }}>t_{\text {tabel }}$, signifikan $<\alpha$ maka Ho ditolak dan Ha diterima

\section{Uji Multikolinearity}

Uji multikolinearity digunakan untuk mengetahui apakah di dalam model regresi yang digunakan terdapat korelasi yang sempurna daitara variabel-variabel yang menjelaskan independen variabel. Suatu model regresi linier akan menghasilkan estimasi yang baik apabila model tersebut tidak mengandung multikolenearity. Multikolenearity terjadi karena adanya hubungan yang kuat antara sesama variabel independen dari suatu model estimasi.

\section{Uji Autokorelasi}

Uji ini dipergunakan untuk melihat kesalahan akibat adanya nilai residual yang tidak bebas diantara variabel yang diobservasi. Umumnya kesalahan disebabkan data time series. Uji ini menggunakan metode durbin watson.

\section{Hasil Dan Pembahasan}

1. Pertumbuhan Ekonomi

\section{Pertumbuhan PDRB Kabupaten LabuhanbatuTahun 1999-2004}

(\%)

\begin{tabular}{|c|c|c|c|c|c|c|c|}
\hline $\mathrm{N}$ & & 1999 & 2000 & 2001 & 2002 & 2003 & $20) 4$ \\
\hline 1. & Pertanian & 4.55 & 495 & 4.93 & 5.25 & 4.24 & 5.01 \\
\hline 2. & Tertambangan dan Tenggalian & 5.39 & 5.12 & 4.31 & 2.58 & 2.26 & 3.12 \\
\hline 3. & Industri Pengolalian & 5.30 & 725 & 4.96 & 5.18 & 5.14 & 4.76 \\
\hline 4. & Listrik, Cas can Air Dersih & 6.23 & 542 & 10.87 & 4.67 & 6.11 & 7.73 \\
\hline 5. & Dangunan & 3.07 & 485 & 2.46 & 2.15 & 2.51 & 2.24 \\
\hline 6. & Terdag ang ann, hotel dan Restoran & 2.75 & 688 & 6.58 & 7.88 & 6.03 & 6.18 \\
\hline 7 . & Tenganghutan dan Komunikasi & 2.81 & 462 & 4.51 & 5.17 & 3.91 & 3.52 \\
\hline 8. & $\begin{array}{l}\text { Keuatugall, Persewaanl darl jass } \\
\text { Pervaghaun }\end{array}$ & 6.58 & 6.10 & 3.96 & 3.66 & 4.65 & 3.65 \\
\hline 9. & Jasa-jasa & 15.89 & 440 & 4.29 & 5.17 & 3.13 & 3.57 \\
\hline & Labuianbatu & 4.98 & 596 & 5.12 & 5.59 & 4.74 & 4.94 \\
\hline
\end{tabular}

Sumber: BPS Labuhanbatu, 2004

2. Perkembangan penerimaan pajak daerah Kabupaten Labuhanbatu 


\begin{tabular}{|c|c|c|}
\hline Tanun & Peserimaat Pajaic & Perkembangai ( $(\%)$ \\
\hline $1,91 / 1992$ & 318.000500 & 69,95 \\
\hline 19921993 & $405.500 \supset 00$ & 69,79 \\
\hline $1993 / 1994$ & 450.500000 & $\$ 6,76$ \\
\hline 19941995 & 667.639300 & 96.87 \\
\hline 19951996 & 871.897500 & 100,00 \\
\hline 19961997 & $1.075 .15 \div 000$ & 95,05 \\
\hline $199 \times 1998$ & $1.28 \% .18,000$ & 96,97 \\
\hline 10981999 & $1.83 \vdots .211000$ & 90,86 \\
\hline $1999 / 2000$ & $2.881 .49: 000$ & 90,15 \\
\hline $2(100$ & $2.392 .00<000$ & 95,67 \\
\hline $2(101$ & $3.630 .25 \pm 000$ & 85,02 \\
\hline $2(002$ & 4.547 .941150 & 111,90 \\
\hline $2(003$ & $5.89 ; .00 \mathrm{C} 000$ & 113,16 \\
\hline $2(004$ & $8.612 .50 \mathrm{C} 000$ & 104,14 \\
\hline
\end{tabular}

Sumber: Dinas Pendapatan Kabupaten Labuhanbatu.

3. Regresi Linier Variabel

Hasil Regresi

\begin{tabular}{cccc|c|}
\hline Varabel & Koefisien & Standar error & T staistik & Probality \\
\hline C & 1629749. & 414804.1 & 3.928962 & 0.0020 \\
X (Pajak & 0.001293 & 0.000121 & 10.69422 & 0.0000 \\
Daerak) & & & & \\
R & 0.905038 & & & \\
R Square & 0.897125 & & & \\
\hline FS tatisik & 114.3663 & & &
\end{tabular}

\section{Koefisien Determinasi $\left(\mathrm{R}^{2}\right)$}

Dari tabel hasil regresi diperoleh $\mathrm{R}$-square $\left(\mathrm{R}^{2}\right)$ sebesar 0.905038 . hal ini berarti bahwa variabel pajak daerah $(\mathrm{X})$ secara bersama-sama mempunyai kekuatan untuk menjelaskan variabel PDRB (Y) sebesar 90.50\%, sedangkan sisanya sebesar 9,50\% dijelaskan oleh variabel lain yang tidak dimasukkan ke dalam model estimasi.

\section{Kesimpulan}

Variabel pajak daerah (X) secara bersama-sama mempunyai kekuatan untuk menjelaskan variabel PDRB (Y) sebesar $90.50 \%$, sedangkan sisanya sebesar 9,50\% dijelaskan oleh variabel lain yang tidak dimasukkan ke dalam model estimasi

\section{Daftar Pustaka}

Boediono, B, 2000. Perpajakan Indonesia,Diadit Media, Jakarta

Badan Pusat Statistik Labuhanbatu, Pertumbuhan Domestik Regional Bruto Tahun 1991-2004 Badan Pusat Statistik Labuhanbatu, Indikator Sosial Labuhanbatu Tahun 2003

Dinas Pendapatan Daerah Kabupaten Labuhanbatu, Pendapatan Pajak Daerah Tahun 19912004 
Gujarati, D. 1978. Ekonometrika Dasar Terjemahan, Erlangga, Jakarta

Kristiadi, J.B.1985. Masalah Peningkatan Pendapatan Asli Daerah (PAD). Prisma, Jakarta. Mardiasmo, 2002. Perpajakan. Andi Offset, Yogyakarta.

Mangkoesoebroto, G. 1993. Ekonomi Publik, Edisi Ke-3, BPFE, Yogyakarta.

Meir,g. M, dan Baldwin, 1985. Ekonomi Pembangunan Negara-Negara Berkembang.Teori dan Kebijakan. Jakarta.

Saragih Juli, 2003. Desentralisasi Fiskal dan Keuangan Daerah Dalam Otonomi, Penerbit Ghalia Indonesia, Jakarta.

Siagian, M,1976. Pajak sebagai Sumber keuangan, IIP, Jakarta.

Soekarwo, 2003. Berbagai Permasalahan keuangan Daerah, Airlangga University Press, Surabaya.

Sidik Machfud, 2004. Bunga Rampai Desentralisasi Fiskal, Direktorat Jendral Perimbangan Keuangan Pusat dan Daerah, Jakarta.

Sujamto, 1993, Perspektif Otonomi Daerah, Rineka Cipta, Jakarta.

Teguh, 1999, Metode Penelitian Ekonomi Teori dan Aplikasi, P.T. Grafindo Persada, Jakarta.

Undang-undang Republik Indonesia Nomor 22, Tahun 1999, tentang Pemerintahan, Daerah, dalam Sepuluh Undang-undang 1999, C.V. eko Jaya, Jakarta. 